\title{
Mercimek Kale-Kalecik-Çengilli Tarihi Yol Güzergâhı: Alternatif Bir Turizm Rotasi*
}

\author{
Historical Route of Mercimek Kale-Kalecik-Çengilli: An Alternative Tourism Route \\ İskender Dölek ${ }^{a, * *}$ \\ ${ }^{a}$ Dr. Öğr. Üyesi, Muş Alparslan Üniversitesi, Eğitim Fakültesi, Muş/Türkiye. \\ ORCID: 0000-0002-5922-8515
}

\section{MAKALE BILGIISI}

Makale Geçmişi:

Başvuru Tarihi: 26 Kasım 2020

Düzeltme Tarihi: 16 Aralık 2020

Kabul Tarihi: 21 Aralık 2020

Anahtar Kelimeler:

Muş

Çengilli

Kalecik

Mercimek Kale

Turizm Rotaları

\section{A R T ICLE INFO}

Article history:

Received 26 November 2020

Received in revised form 16 December 2020

Accepted 21 December 2020

\section{Keywords:}

Muş

Çengilli

Kalecik

Mercimek Kale

Tourism Routes
ÖZ

Muş ili doğal ve kültürel anlamda birçok varlığa sahiptir. En az bilinenler kadar bilinmeyen doğal ve kültürel varlıklar da ilde yer almaktadır. . Mercimek Kale - Kalecik- Çengilli güzergâhı da bunlardan biridir. Ülkemizin farklı yerlerinde bulunan ve bugün çeşitli etkinliklerle (yürüyüş, maraton vb) önemli turizm rotalarına dönüştürülen Tarihi Yollar (Likya gibi) sadece bulundukları bölgelerden değil dünyanın birçok yerinden düzenlenen etkinliklerle binlerce ziyaretçi (turist) çekmektedir. Mercimek Kale-Kalecik-Çengilli Tarihi Yol Güzergâhı da tarihsel süreci ortaya konulabildiği takdirde böyle bir potansiyele sahiptir.

\section{Giriş}

Muş ili Doğu Anadolu Bölgesinde Yukarı Murat Van bölümünde yer alır (Harita1). Anadolu'nun kadim şehirlerin den biridir. Anadolu'nun yurt edinilmesinde de ayrı bir yere ve öneme sahiptir. Buna rağmen Sosyo-ekonomik anlamda ülkemizin en geri kalmış illerinden biridir (Dölek, Şaroğlu 2017, Arslan,2019). İl için bu çok yeni bir durum değildir. Yolu bir şekilde Muş’a düşen birçok seyyah da bu duruma

\begin{abstract}
A B S T R A C T
Although Muş province has many natural and cultural assets, it many more unknown natural and cultural assets. The route of Mercimek Kale - Kalecik - Çengilli is one of these values. Historical routes (such as Lycia), which are located in different parts of Turkey and transformed into important tourism routes with various activities (walking, marathon, etc.), attract thousands of visitors (tourists) not only from their regions but also from different parts of the world. The historical route of Mercimek Kale-Kalecik-Çengilli has such a potential in case that its historical process can be revealed.
\end{abstract}

* Bu çalışma, 22-23 Ekim 2020 tarihlerinde Muş Alparslan Üniversitesinde düzenlenen II. Uluslararası Muş Sempozyumunda sözlü bildiri olarak sunulmuştur.

** Sorumlu yazar/Corresponding author.

e-posta:isdolek@gmail.com 
Bitlis'in bir nahiyesi olan Muş'u eski bir şehir olarak vasıflandırır. Şehrin bir fersah güneyinde bulunan kalesi ve yapıları harap bir şekilde ayaktadır. Bir dağın dibinde, bir vadi ağzında kurulmuş küçük bir belde olarak tanımlar (Kayhan,2018). 19. Yy da yolu Muş’a düşen bir seyyah Southgate, bu durumu "Muş'un içine girince uzaktan hissedilen güzellikten eser kalmaz" şeklinde tasvir etmiştir. Southgate'in verdiği malumata göre sokaklar çok kirli, düzensiz ve dardır (Akt. Bingül,2019).

$\mathrm{Bu}$ durumun yaşanmasında çok farklı görüşler ileri sürülse de il için seçilen yanlış projeler ya da doğru projelerin yanlış kurgulanması nedeniyle Muş ili bir türlü istenen gelişimi gösterememiştir. Yakın zamana kadar nüfusu özellikle göçlerle azalan il, iş olanaklarının da oldukça sınırlı olduğu ekonomik bir yapıya sahiptir.

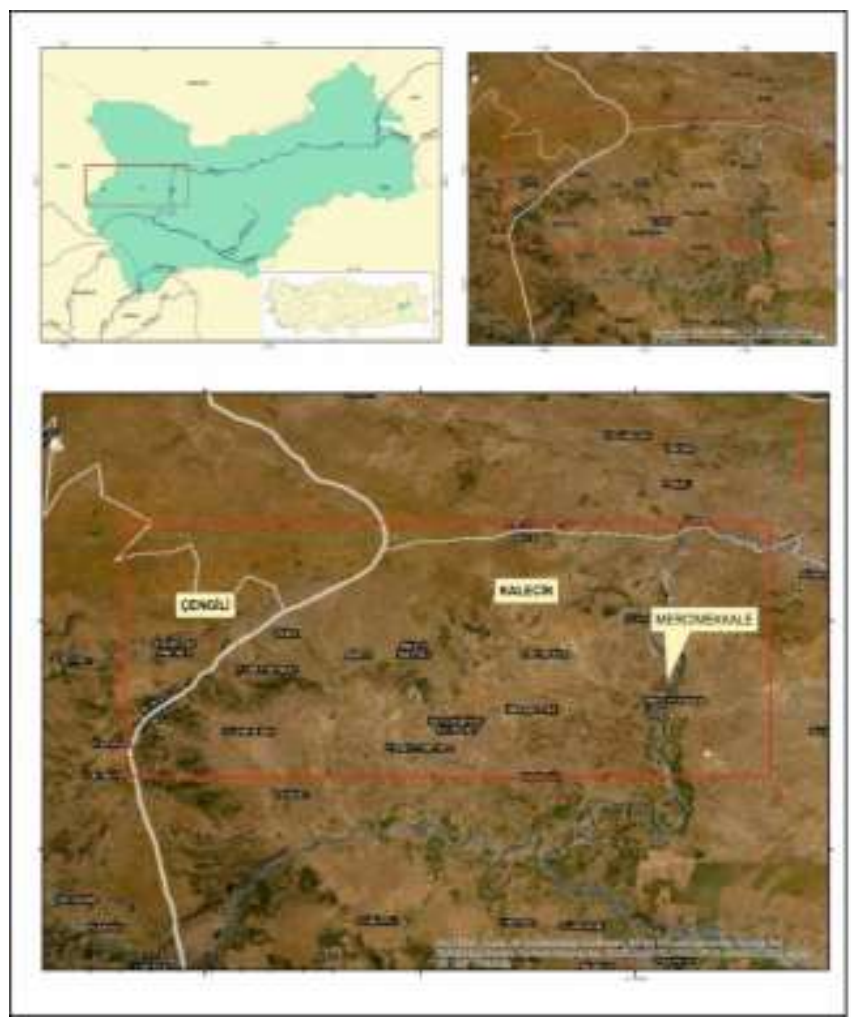

Harita 1: Çalışma alanına ait yer bulduru haritası.

Türkiye'nin en büyük ovalarından birine sahip olmasına rağmen tarımsal üretimin il ekonomisine katkısı azdır. Fiziki coğrafya şartlarının (iklim, toprak özellikleri vb.) ekonomik faktörleri baskılaması yanında Doğu ve Güneydoğu Anadolu Bölgelerinde yaşanan terör sorunu da kırsal alanların boşaltılmasında önemli bir faktördür. $\mathrm{Bu}$ anlamda Muş ilinde 1993 yllından itibaren toplamda 8 köy, 43 mezra boşaltılmış ve bu yerleşmelerde yaşayan nüfus (277 hanedeki toplam 1965 kişi) göç etmek zorunda kalmıştır (Durmuş, Dölek 2019).

Muş, sanayi ve şehirleşme olgusunun gelişmediği ekonomik faaliyetlerin büyük bir bölümünün doğal koşulların denetiminde olduğu tipik bir Doğu Anadolu ilidir. Başka bir ifade ile Muş ilinde özellikle kırsal alanlarda gerçekleştirilen beşeri ve ekonomik faaliyetler, doğal ortam koşullarının denetimindedir. Muş ilinde her ne kadar il ve ilçe merkezlerinde nüfus yoğunlaşsa da yerleşme ve nüfusun hemen hemen ilin tamamına farklı yerleşme tiplerinde de olsa yayıldığını görmek mümkündür.
Sanayinin gelişmediği, iş olanaklarının sınırlı olduğu ortamlarda, bu durum doğal koşulların belirleyici bir sonucudur. Muş ve Bulanık fonksiyonları açısından şehir özelliği, diğer ilçe merkezleri ise kasaba özelliği göstermektedir. İlçe merkezleri dışında 17 belde belediyesi bulunmaktadır. $\mathrm{Bu}$ beldeler tarım kasabası özelliği göstermektedirler. Bu kasaba yerleşmelerinin 8'i Merkez, 6'sı Bulanık ilçesindedir. İlçe merkezleri de dâhil olmak üzere Hasköy, Korkut ve Malazgirt'te 2'şer kasaba bulunmaktadır. Nüfusun \%30'u şehirlerde, \% 23'ü kasabalarda ve \%47'si köylerde yaşamaktadır (Durmuş, Dölek 2019).

Muş ilinin gelişmesinde hayvancılıkla birlikte turizm önemli bir potansiyele sahiptir (Dölek, Şaroğlu 2017, Arslan,2019). 2013 itibari ile Muş ilindeki toplam büyükbaş hayvan sayısı, Türkiye genelindeki büyükbaş hayvan sayısının yaklaşık \% 2'sini oluşturmaktadır (TÜİK, 2014). 2011 yılı itibari ile Türkiye'deki küçükbaş hayvan sayısının \% 4,9'unu oluşturmaktadır (Muş İl Gıda, Tarım ve Hayvancılık Müdürlüğü, 2011, akt.Ersungur, Aslan 2014).

Özellikle ilin sahip olduğu doğal güzellikler yanında çok farklı kültürleri barındırması ve tarihin farklı dönmelerine ait tarihsel yapılara sahip olması turizmin gelişmesi için önemli unsurlar olarak değerlendirilmektedir.

$\mathrm{Bu}$ çalışmaya konu olan Mercimek kale, Kalecik ve Çengilli Manastırı gibi çok fazla çalışılmamış ya da haklarında fazla bir bilgiye sahip olmadığımız birçok doğal ve kültürel varlık Muş ilinde yer almaktadır.

\section{Amaç}

$\mathrm{Bu}$ çalışmanın en önemli amacı bu taşınmaz kültürel miras olarak değerlendirebileceğimiz tarihi yapıların, arasında bir bağın, tarihsel bir birlikteliğin olabilirliğine dikkat çekmek tir. Farklı bilim alanları tarafından yapılacak çalışmalarla bu bağ daha geniş ve daha doğru bir şekilde ortaya konulabilinir. $\mathrm{Bu}$ tarihsel yapıların arasında ki bağa bağlı olarak da Dünyanın birçok ülkesinde olduğu gibi, ülkemizde de 2010 yılından beri düzenlenen "Likya Yolu" maratonu gibi bir organizasyonun yapılması ile ilin turizm potansiyeline bir alternatif değer sunulabilir.

\section{Veri ve Yöntem}

$\mathrm{Bu}$ çalışmada, çalışmaya konu olan mekanlara ait verilerin toplanmasında literatür taraması yapılmıştır. Yalnız söz konusu kültürel varlıklarla ilgili direkt ya da dolaylı çalışma sayısı oldukça azdır. Üç yapı arasında bir bağ olduğunu ifade eden çalışma ise hiç yoktur. Bu çalışmada ki üç mekâna ait görüş analizleri ArcGIS10.5 programında 10x10 metre çözünürlükte DEM (Digital Elevation Model) kullanılarak, Spatial Analysis aracı altında yer alan Visibly özelliği kullanılarak yapılmıştır.

\section{Mercimek Kale, Kalecik Ve Çengilli Manastırı}

Mercimek Kale, Kalecik, Çengilli Manastırı Muş ilinde yer alan taşınmaz miras olarak değerlendirilebilecek önemli kültürel öğelerdir. Taşınmaz kültürel miras dediğimiz tarihi çevreler, yapıldıkları dönemlerin duygu, düşünce, eğitim, yaşam tecrübeleri birikiminin anlatıldığı, ortak bir dil barındıran yerleşmelerdir. Tarihi kentler ve dokular, kültürel peyzajlar, anıtsal yapılar, arkeolojik alanlar taşınmaz kültürel mirası oluşturan, geçmişle gelecek 
arasında bir köprü kuran mekânlardır ve korunmalarının yanı sıra sürekliliklerinin sağlanabilmeleri de ayrıca önem taşımaktadır (Bulakcıbaşı,2020).

\subsection{Mercimek Kale}

Mercimek Kale (Foto 1)Muş merkez ilce sınırları içerisinde Muş-Varto karayolu üzerinde yer alır. Mercimek Kale İl sınırları içerisinde yer alan çok sayıda ki höyükten biridir. Halk arasında insan eliyle oluşturulan bir yapı olarak değerlendirilir. Mekânla ilgili anlatılan hikâyelerde bunu destekler niteliktedir. Ancak, Mercimek Kale literatürde Sergen formasyonu olarak adlandırılan birimin (riyolitleri) içerisinde yer alan bir domdur. Sergen formasyonu riyolitik lav ve tüflerden oluşmuştur. Bu formasyon Muş ovasının batısında ve Murat Nehri kenarındaki Mercimek Kale köyü yakınında da gözlenmektedir. Riyolitler Miyosen ve Erken Pliyosen yaşlı birimleri kesmektedir. Birimin Miyosen yaşlı kirectaş1-killikirectaşını kestiği, dokanakta metamorfizmaya da uğrattığ1 gözlenebilmektedir (Şaroğlu, Güner 1981, Şaroğlu,1985, Dölek, Şaroğlu,2017, Dölek Şaroğlu,2020).

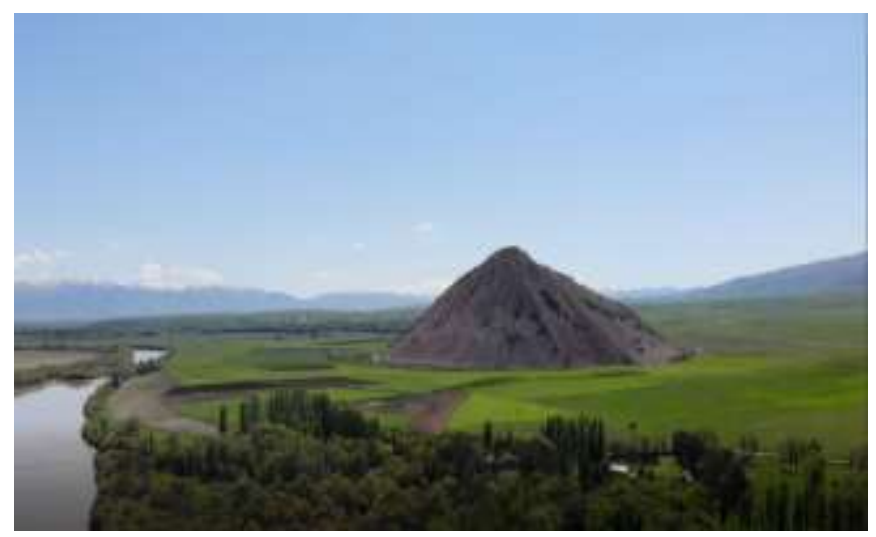

Foto1: Mercimek Kale

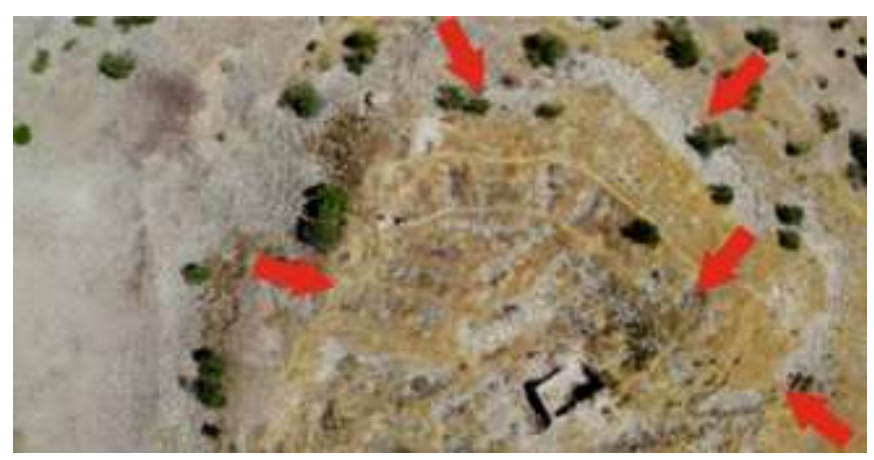

Foto2: Mercimek Kale üzerinde yer alan kuleye ait kalıntılar.

Pleistosen yaşlı Anzar formasyonunda blok ve cakılları izlenebilmektedir. Bu nedenle birimin yaşı Geç PliyosenPleistosen olarak kabul edilmektedir (Şaroğlu, Güner 1981, Şaroğlu,1985, Dölek, Şaroğlu,2017, Dölek Şaroğlu,2020).

$\mathrm{Bu}$ doğal yapı üzerinde inşa edilmiş kaleye (kule) ait kalıntılar yer almaktadır. Kule çevredeki yol güzergâhları dışında döneminin önemli yapı ve yerleşmelerini de koruma ve güvenliklerini sağlamak amacıyla inşa edilmiş olmalıdır. Anadolu'da yer alan benzer misyona sahip birçok yapıyla (Bayburt Kalesi, Gümüşhane Keçi Kalesi vb.) aynı mimari özelliklere sahiptir. Kule (Kale) sağlam bir zemin üzerine inşa edilmiştir.
Osmanlı Devleti'nin, 16. yüzyılın sonlarına doğru İran ve Avusturya ile yaptığı savaşların uzun süreli olması devleti hem askeri hem de mali açıdan olumsuz etkilemiştir. 17. yüzyılda da devam eden bu durum içeride karışılılklara neden olmuştur. Dolayısıyla 17. yüzyıl Osmanlı Devleti genelinde asayiş olaylarının had safhaya ulaştığı bir dönemdir. Bu yüzyılda Osmanlı ordusu bir taraftan batı ve doğu cephelerinde hâkimiyetini korumak için çabalarken, diğer taraftan da içerdeki âsilerle mücadele etmek zorunda kalmıştır. Muş ve çevresinde isyan eden Alaattin Bey de bunlardan biridir. Alaattin Bey'in inşa ettiği yapılardan biride Muş kasabasına beş saatlik bir vadi üzerinde yaptırılan Mercimek Kalesiydi. Bu kale güçlü bir kaya üzerinde üç katlı sur şeklinde mermer taşlardan yaptırılmıştı. Mercimek kalesi üç yüz zirâ'dan fazla bir alanı kaplamaktaydı. Kalenin içinde yine mermer taşlarından doldurulan dört adet top tabyası vardı. Ayrıca çevreyi gözetlemek için kaleye dört adet kule de yaptırılmıştı. Mercimek kalesini takviye için kalenin varoşlarında bir kule daha yaptırılmış ve yine kalenin etrafına derin hendekler de kazılmıştır (Uzun,2018). İsyanın bastırılması ile birlikte Mercimek kalede yıkılmıştır.

Sonrasında meydana gelen bazı isyanlarda da kalenin yeniden inşa edilerek kullanılması yörenin güvenliği için oldukça önemli bir konumda olduğunu göstermektedir. Bu durum sadece 17-18 yy. la sinırlı olmasa gerektir. Mercimek Kalenin batısında yer alan Kalecikle birbirlerini gören bir konumda inşa edilmeleri (Harita,2), batıya doğru (Bingöl) devam eden bir yolun varlığını (Ticaret-Hac yolu) düşündürmektedir. $\mathrm{Bu}$ düşüncenin doğruluğu farklı bilimsel alanlardan bilim insanlarının çalışmalarıyla desteklenecek ya da çürütülecektir.

\subsection{Kalecik Kalesi}

Kalecik Kalesi Muş Merkeze yaklaşık 32 km uzaklıktadır (Foto3). Sahip olduğu yapısal özeliklerle çevresindeki doğal diğer yapılardan kolayca ayırt edilir. Zira zirve kısmı insan eliyle düzleştirilmiştir. Kalecik Köyü sınırları içerisinde yer alan kalenin etrafı tam olarak gezildiği zaman kale surları çok iyi bir şekilde belli olmaktadır. Kale duvarlarını oluşturan moloz taşların üst kısımlarından eser kalmamış sadece alt temelleri görülmektedir. Kalenin üst kısımlarında, sur duvarlarında kullanılan malzemenin aynısının Kalenin iç mekânlarında da kullanıldığı ortaya çıkan yap1 kalıntısından çok bariz bir şekilde görülmektedir. Gerek kalenin eteklerin de olsun gerekse üst kısımlarında o dönemde kullanılan birçok çanak-çömlek parçaları (Foto,5) görülmektedir. Kalenin kültürel zenginliği onu birçok talihsiz durumla karşı karşıya getirmiştir. Yerel hak tarafından bugün birçok yerde kaçak kazılar yapılmış ve bu kaçak kazılar kalenin kültürel dokusunu ciddi manada tehdit eder hale gelmiştir. Kalenin doğu tarafinda yapılan kaçak kazılar sonucunda kaleye ait bir adet burç veya destekleme kulesi ortaya çıkarılmış tır. Kelenin üstünden baktığımız zaman o dönemki yerleşim yerlerinden kalan ev kalıntıları kendini çok iyi göstermekte dir. 


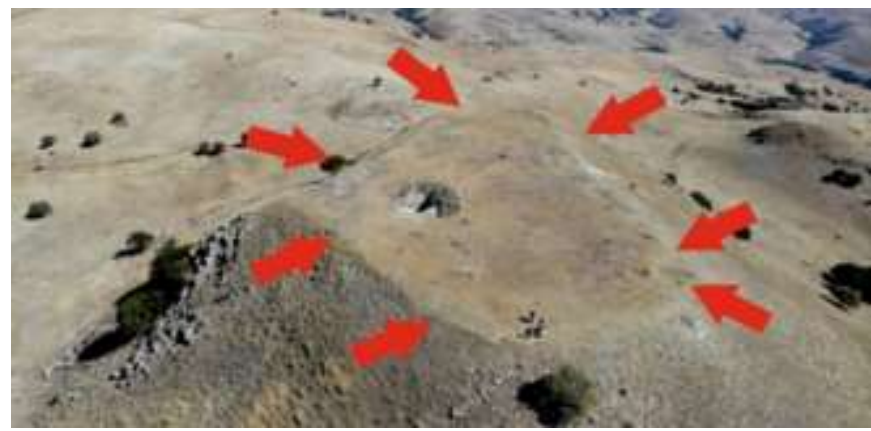

Foto 3: Kalecik Kalesi

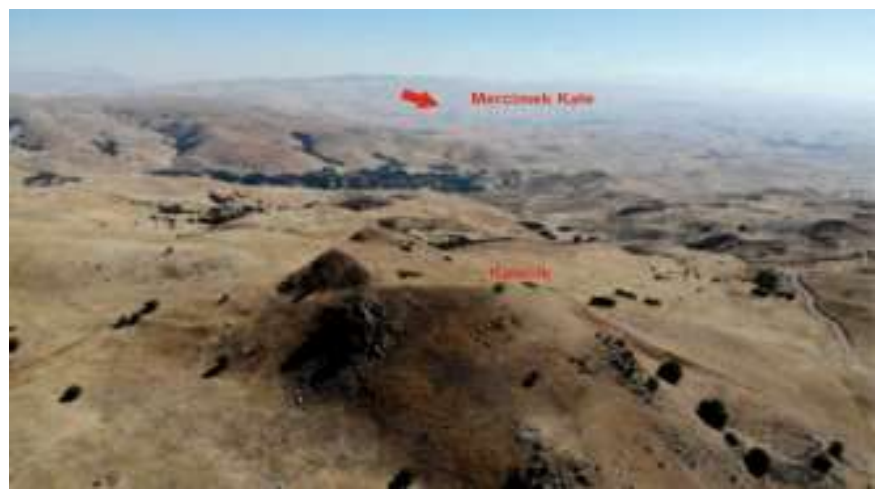

Foto 4: Kalecik Kalesinden Mercimek Kale’ye bakış

Kalecik kalesi çevresinde yaptığımız gözlemlerde çok sayıda farklı dönemlere ait çömlek parçalarına rastlamamız (Foto 5) ve bunlardan bazılarının morfolojik olarak 1213yy. tarihlendirilebiliyor olması yörenin tarihsel misyonu ile ilgili daha detaylı çalışmalar yapılmasını zorunlu kılmaktadır. Kale çevresinde çok sayıda obsidyen yongalarına da rastlamak mümkündür.

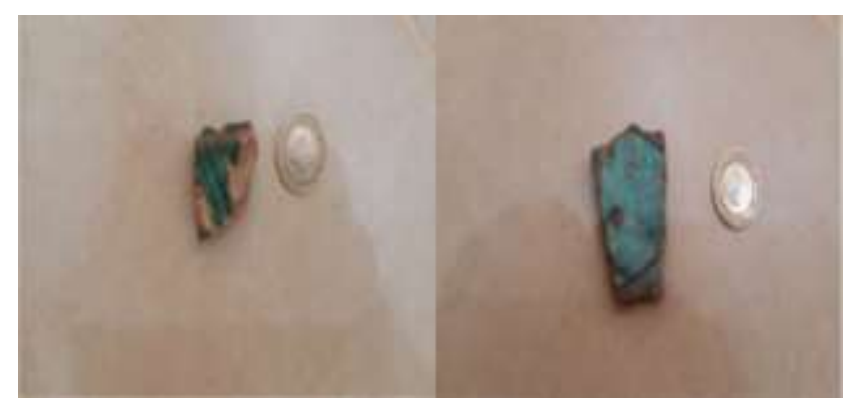

Foto 5: 12-13 yy ait (Selçuklu) çömlek parçaları.

\section{3. Çengilli Manastırı}

Manastır, belli bir Hıristiyan tarikatına mensup fertlerin çalışma, eğitim ve ibadetlerini tamamen Tanrı'ya has k1lmak üzere toplumdan ayrı bir cemaat halinde yaşayabilmelerini temin etmek maksadıyla düzenlenmiş olan yapı ya da yapılar topluluğudur (Polat,2020). Muş Surp Garabed Manastırı, Muş ili sınırları içerisinde yer alan en eski Ermeni manastırlarından biridir. Günümüzde Çengelli (Çengilli) Kilisesi olarak bilinen Surp Garabed Manastırı, Muş-Bingol karayolunun kuzeybatı dağ eteklerine inşa edilmiş olup şehir merkezinden $48 \mathrm{~km}$. uzaklıkta Muş (Daron)'un ilk ve en büyük ErmeniApostolik manastırıdır (Beroje,2020). Yapı çok sayıda eklentiye sahiptir (Kilavuz,2013).

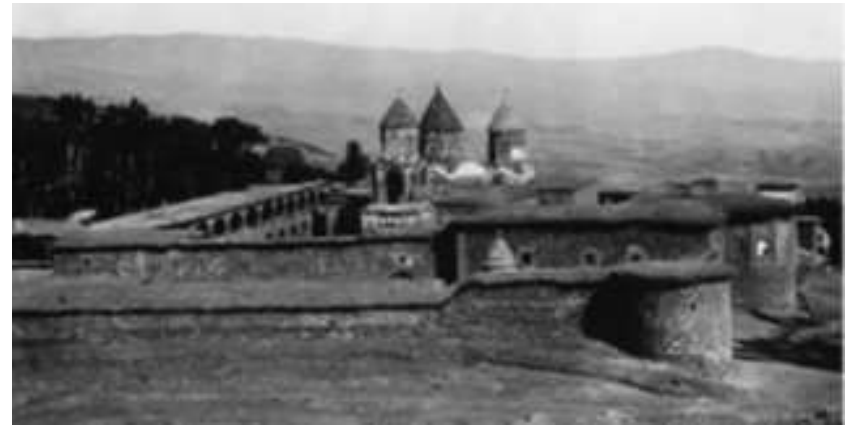

Foto 6: Çengilli Kilisesine ait 1928 tarihli bir fotoğraf

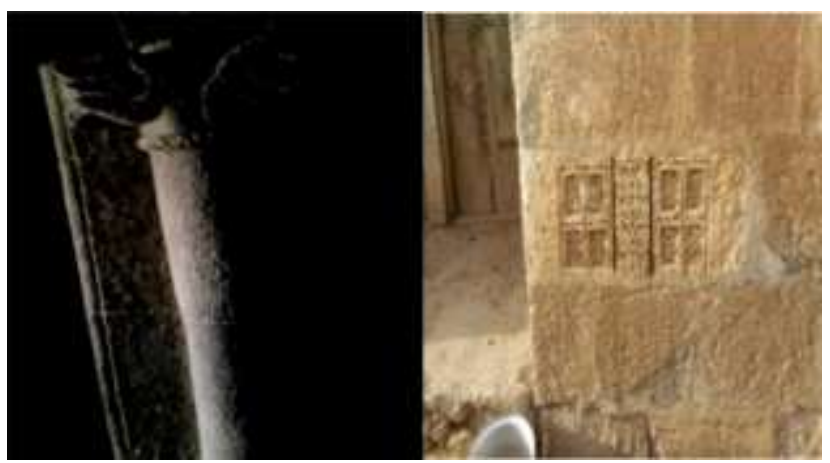

Foto 7: Çengilli kilisesindeki taş işçiliğine örnek

Apostolik (Elcisel) Kiliseler içerisinde geçiş güzergâhında yer alan manastırın kuzey doğusunda Ecmiadzin Katolikos luğu ve doğusunda Ahtamar Katolikosluğu bulunmaktadır. Pagan dönemi tapınakları olan Demeter ve Kisan harabeleri üzerine inşa edilen Surp Garabed Manastırı, IV. yüzyıldan $\mathrm{XX}$. yüzyıla kadar bölgede yaşayan Ermenilerin ruhani merkezi olarak varlığını korumuştur. Tarihsel süreçte yüksek ruhani makamlar arasında bulunan manastırın Batı Ermenileri için merkezi konumda yer aldığını ifade etmek gerekiyor. Bunun yanısıra Aziz Krikor, Kayseri'den getirtti ği Aziz Hovhannes Migırdic'in kemiklerini "kutsal emanet ler" olarak manastıra koyduğu da biliniyor. Bu özellikleri nedeniyle, tarihsel süreçte manastıra dişardan pek çok dindar Hristiyanların hac için gelip ziyaret ettikleri dini bir merkez konumunda olmuştur. Bu konumundan dolayı Surp Garabed Manastırı'nın bölgedeki en etkili ruhani merkez olduğu vurgulanmalıdır. Daha da mühimi Surp Garabed Manastırı, bu etkinliğini hem ruhani hem de idari olarak Osmanlı'nın son dönemine kadar korumuştur (Beroje,2020).

$\mathrm{Bu}$ üç yapının, birbirini görecek şekilde konuşlandırılmış olması (Harita 2), tarihsel süreçlerinin daha detaylı bir şekilde araştırılmasını zorunlu kılmaktadır. Bizim kanaatimiz Mercimek Kale ve Çengilli hattı boyunca tarihi süreç içerisinde "Hac Yolu" ya da "Ticaret Yolu" olarak kullanılmış ama bugün aynı öneme sahip olmayan bir yol güzergâhının var olduğudur. $\mathrm{Bu}$ durum yapılacak daha detaylı çalışmalarla değerlendirilebilinir. 


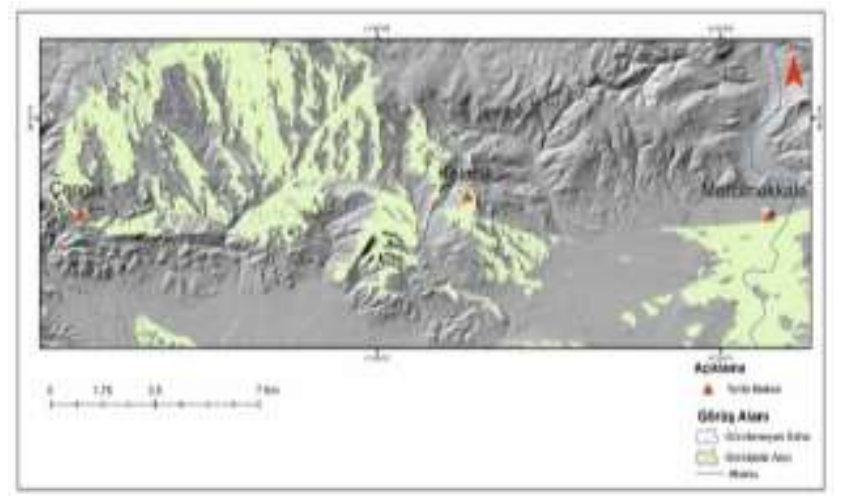

Harita 2. Mercimek kale, Kalecik, Çengilli tarihi mekânlarına ait görüş analizi.

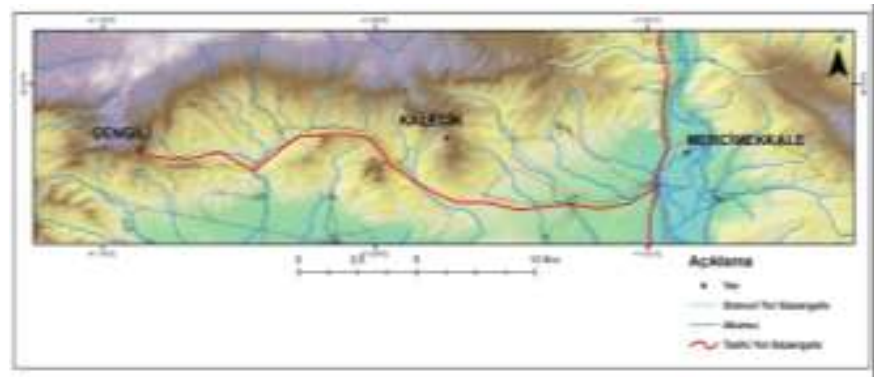

Harita 3. Mercimek Kale, Kalecik, Çengilli tarihi mekânlarının da üzerinde yer aldığı muhtemel tarihi yol güzergâh1.

\section{Sonuç}

Muş ili zengin bir tarihi geçmişe sahiptir. İl bilinenler dışında bilinmeyen birçok kültürel değeri bünyesinde barındırmaktadır. Bunlar tanıtılarak, farkındalık oluşturularak koruma temelli farklı etkinliklerle kullanıma sunulabilir.

Ülkemizin farklı yerlerinde bulunan ve bugün çeşitli etkinliklerle (yürüyüş, maraton vb) önemli turizm rotalarına dönüştürülen Tarihi Yollar (Likya gibi) sadece bulundukları bölgelerden değil dünyanın birçok yerinden düzenlenen etkinliklerle binlerce ziyaretçi (turist) çekmektedir. Mercimek Kale-Kalecik-Çengilli Tarihi Yol Güzergâhı da tarihsel süreci ortaya konulabildiği takdirde böyle bir potansiyele sahiptir. Böyle bir etkinliğin yapılması ile turizm anlamında da bir katma değer sağlayacaktır.

\section{Kaynakça}

Arslan. Ö. (2019). Muş Sanayi Modeli. Ankara. Çizgi Kitabevi.

Beroje, R. (2020). Muş Surp Garabed Manastırı Üzerine Notlar. Editörler: S. Karakaya/O. Keskintaş. (111130) Muş Kitabı. İstanbul. Pınar Yayınları.

Bingül, Ş. (2019). 19. Yüzyıl Osmanlı Modernleşmesi Bağlamında Muş Sancağının Islahat Hareketleri. Editör: Ercan Çağlayan. (17-33) "BURASI MUŞ'TUR”. İstanbul. Pınar Yayınları.

Bulakcıbaşı, N. (2020). Muş’taki Tarihi Eserlerin Ve Alanların Tahribatı Üzerine Bir Değerlendirme.
Editörler: S. Karakaya/O. Keskintaș. (315-372) Muş Kitabı. İstanbul. Pınar Yayınları.

Durmuş E., Dölek İ (2019). Muş İl'inde Yerleşme Tiplerinin Coğrafi Dağılışı. International Journal of Geography and Geography Education 39 (39):256278

Dölek, İ., Şaroğlu, F. (2017). Muş İli Ve Yakın Çevresinde Jeoturizm Acısından Değerlendirilebilecek Jeositler. Firat Universitesi Sosyal Bilimler Dergisi 27-1-16

Dölek, İ., Şaroğlu, F. (2020). Muş İlinde Turizm Acısından Değerlendirilebilecek Doğal ve Kültürel Varlıklar. Editörler: S. Karakaya/O. Keskintaş. (373-390) İstanbul. Pınar Yayınları.

Erdoğan, P. (2020). Osmanlı Devleti’nde Manastırbend Cezasının Tatbikinde Surp Nişan ve Anna Manastırları Örnekleri. Tarih ve Gelecek Dergisi, Haziran,Cilt 6, Sayı 2

Ersungur, Ş. \& Arslan M. (2014). Muş İlinin Gelişme Potansiyelinin Swot Analizi İle İncelenmesi Atatürk Üniversitesi İktisadi ve İdari Bilimler Dergisi, Cilt: 28, Say1: 4.

Kılavuz, B. , N. (2012). Ortaçağ ve Sonrası Muş İli Yüzey Araştırması 2009- Bulanık. Tarih, Kültür, Sanat Araştırmaları dergisi. Cilt 2, Sayı1

Kılavuz, B. , N. (2013). Ortaçağ ve Sonrası Muş İli Yüzey Araştırmas1 -2010- Varto. Tarih, Kültür, Sanat Araştırmaları dergisi. Cilt 2, Sayı1

Lynch, H. F. B. (1965). Armenia, Travels and Studies. Vol.II, Khayats, Beirut

Kayhan, H. (2018). Sökmenli Hâkimiyetinde Muş’un Tarihi Gelişimi. Tarih Ve Kültür Bağlamında Muş Uluslararası Sempozyumu Bildirileri. (126-133). Muş

Özdal A.,N. (2018). İmparatorlukların Gölgesinde ve Kendi Halinde: Ortaçağ'da Muş'un Toplumsal Hareketliliği ve Ekonomik Yapısı. Tarih Ve Kültür Bağlamında Muş Uluslararası Sempozyumu Bildirileri (98-113).Muş

Şaroğlu, F. Guner, Y. (1981). Doğu Anadolu'nun Jeomorfolo jik Gelişimine Etki Eden Ogeler: Jeomorfoloji, Tektonik, Volkanizma İlişkileri, TJK Bülteni, 24, 2, 119- 130

Şaroğlu,F. (1985). Doğu Anadolu'nun Neotektonik Donemde Jeolojik ve Yapısal Evrimi. Doktora Tezi. İstanbul Universitesi Fen Bilimleri Enstitüsü.

Uzun C. (2018). Muş Mütesellimi Alaaddin İsyanı Tarih ve Gelecek Dergisi, Nisan 2018, Cilt 4, Say1 1

\section{Internet Kaynakları}

https://www.kulturportali.gov.tr/turkiye/mus/gezilecekyer/k aleck-kales adresinden alındı.

https://mus.ktb.gov.tr/TR-56180/sit-alanlari.html adresinden alındı.

https://deramus.tr.gg/resimler.htm adresinden alındı. 